\title{
Cross Species/Genera Transferability of SSR Markers, Genetic Diversity and Population Structure Analysis in Gladiolus (Gladiolus $\times$ grandiflorus L.) Genotypes
}

\section{Varun Hiremath}

Indian Agricultural Research Institute

Kanwar Pal Singh ( $\sim$ kanwariari@gmail.com )

IARI: Indian Agricultural Research Institute https://orcid.org/0000-0002-1173-8428

\section{Neelu Jain}

Indian Agricultural Research Institute

\section{Kishan Swaroop}

Indian Agricultural Research Institute

Pradeep Kumar Jain

National Institute of Plant Biotechnology

\section{Sapna Panwar}

Indian Agricultural Research Institute

Nivedita Sinha

Indian Agricultural Research Institute

\section{Research Article}

Keywords: Cross transferability, genetic diversity, gladiolus, microsatellites, conservation

Posted Date: July 9th, 2021

DOI: https://doi.org/10.21203/rs.3.rs-673512/v1

License: (c) (i) This work is licensed under a Creative Commons Attribution 4.0 International License. Read Full License 


\section{Abstract}

Genetic diversity and structure analysis using molecular markers is necessary for efficient utilization and sustainable management of gladiolus germplasm. Genetic analysis of gladiolus germplasm using SSR markers is largely missing due to scarce genomic information. In the present investigation, we report $66.66 \%$ cross transferability of Gladiolus palustris SSRs whereas $48 \%$ of Iris EST-SSRs were cross transferable across the gladiolus genotypes used in the study. A total of 17 highly polymorphic SSRs revealed a total 58 polymorphic loci ranging from two to six in each locus with an average of 3.41 alleles per marker. PIC values ranged from 0.11 to 0.71 with an average value of 0.48 . Four SSRs were selectively neutral based on Ewens-Watterson test. Analysis of genetic structure of 84 gladiolus genotypes divided whole germplasm into two subpopulations. 35 genotypes were assigned to subpopulation 1 whereas 37 to subpopulation 2 and rest of the genotypes recorded as admixture. Analysis of molecular variance indicated maximum variance $(53.59 \%$ ) among individuals within subpopulations whereas $36.55 \%$ of variation observed among individuals within total population. Least variation $(9.86 \%)$ was noticed between two subpopulations. Moderate $\left(F_{S T}=0.10\right)$ genetic differentiation of two subpopulations was observed. Grouping pattern of population structure was consistent with UPGMA dendrogram based on simple matching dissimilarity coefficient (ranged from 01.6 to 0.89 ) and PCoA. Genetic relationships assessed among the genotypes of respective clusters assist the breeders in selecting desirable parents for crossing. SSR markers from present study can be utilized for cultivar identification, conservation and sustainable utilization of gladiolus genotypes for crop improvement.

\section{Introduction}

Gladiolus (Gladiolus $\times$ grandiflorus L.) is a commercial bulbous flower cultivated worldwide for its attractive, multicoloured spikes. Gladiolus is one of the largest genera (> 265 species) in the most diverse family Iridaceae [39]. Diploid $(2 n=30)$ species include majority of the wild species whereas modern cultivars are tetraploids [14]. Its cut flowers are widely used for decorating vases, bouquet preparation and flower arrangements with huge demand in domestic as well as international markets. Cultivated gladioli are believed to be originated from natural hybridization among number of wild species $[1,14]$. It is easy to hybridize gladioli owing to their outbreeding nature and high heterozygosity. Hybridization and polyploidy have been greatly responsible for the evolution of gladiolus [25]. As a consequence of continuous hybridization and selection, gladiolus has been endowed with amazing flower diversity in terms of colour, size, shape and growth habit. Development of novel gladiolus varieties is a continuous process to meet consumer demand in floriculture market. Assessment of genetic variability for superior desirable traits will assist in selection of elite genotypes for crossing programme. Further, understanding the genetic relationship of the parent cultivars would enhance the chances of obtaining new varieties. Also, genetic diversity analysis is a prerequisite for efficient utilization and conservation of existing gladiolus germplasm.

Phenotypic variability of any plant is a result of differences in either DNA sequences or specific genes or modifying factors [5]. Characterization and genetic diversity analysis of a crop germplasm using morphological and physiological traits is not reliable because they are non-abundant and their expression is influenced by environment changes. Molecular markers circumvent the demerits of non-conventional markers and act as efficient tools to differentiate the closely related genotypes at genotypic level. Characterization of gladiolus cultivars using DNA markers is essential to establish clear distinction between accessions, identification of desirable source for biotic and abiotic stress tolerance, detection of genetic redundancy and in monitoring genetic diversity changes during conservation. In addition, the accurate identification, documentation and conservation of cultivars or breeding lines is very important in order to protect the plant breeder's rights owing to influx of huge number of new varieties into global markets every year [11]. 
Application of molecular markers for germplasm characterization, conservation and crop improvement of gladiolus is very limited despite its popularity. In previous reports, molecular markers such as RAPD - Random Amplified Polymorphic DNA [23, 36], ISSR - Inter Simple Sequence Repeats [4, 37, 43], SCAR - Sequence Characterized Amplified Region [19, 41] and AFLP - Amplified Fragment Length Polymorphism [18, 36, 46] have been utilized for the assessment of genetic diversity and phylogeny of gladiolus species and cultivars. However, more reliable and easily reproducible markers like SSRs (Simple Sequence Repeats) are meagre in gladiolus.

SSRs have been most preferred markers for genetic studies due to their co-dominant inheritance, high reproducibility, high polymorphism, excellent genome coverage and multi-allelic nature [29]. Developing a new set of SSRs for concerned species is a costly affair and consumes more time as it involves sequencing of targeted genomic regions [44]. Moreover, efficient sequencing requires the intended crop to be diploid, homozygous and with a small genome size. In bulbous flowers, large sequencing efforts are scarce and sequence information is lacking or rather very limited [17]. Sequencing in cultivated gladiolus is difficult due to its large genome size and high heterozygosity. The synteny among the conserved genomic regions of crops belonging to same family may be utilized to study comparative genomics. Thus, SSR markers identified in one plant species can be used directly to study genetic diversity and evolutionary history across closely related species. Heterologous amplification of microsatellites relies on the nucleotide sequence similarity across flanking regions in genome of related species. Therefore, examining cross transferability of SSRs may reduce cost and time required for designing and synthesis of SSRs particularly in species with limited or no genomic information [27].

In last few years, microsatellite markers have been developed for iridaceous flowers like Crocus sativus [24], Herbertia zebrina [10], Sisyrinchium micranthum [47]. Few chloroplast SSRs have been developed from plastid sequences of gladiolus genus and are available in public domain [40]. Genomic SSRs with high discriminating power have also been reported recently in Gladiolus palustris, an endangered European tetraploid species [20]. Expressed Sequence Tags (EST) derived SSRs have been developed for Iris species through sequencing approach [50]. Chloroplast SSRs were expected to have high cross species transferability because of their presence in gene-rich regions [48]. SSR markers derived from ESTs or transcriptome have high rate of cross transferability as they are located very close to or within functional genes. Therefore, they are highly conserved and often show significant polymorphism among plant species [15]. Cross transferability of SSRs have been investigated in few ornamental plants like Aspidistra spp. [12], cactii [2]. So far, there are no reported studies on cross species and cross genera transferability of genomic or EST derived SSRs in gladiolus. Furthermore, microsatellites information on gladiolus species and related genera available in NCBI website has not been utilized to assess genetic diversity and characterization of gladiolus genotypes. With these facts, the current study utilized potential microsatellites from related species and genera to detect extent of cross transferability as well as to analyze genetic diversity, population structure and infer genetic relationship among gladiolus genotypes.

\section{Materials And Methods}

\section{Plant material and DNA isolation}

Planting material consisted a total of 84 Indian and exotic bred gladiolus genotypes collected from different research institutes across India and maintained at research farm of Division of Floriculture and Landscaping, ICAR-Indian Agricultural Research Institute, New Delhi (Table S1). Total genomic DNA of selected plants of individual genotype was isolated from young, healthy leaves using modified CTAB protocol (Doyle and Doyle 1990) and further purified to remove excess salts and phenolic residues. The purified genomic DNA was subjected to gel electrophoresis on $0.8 \%$ agarose gel stained with ethidium bromide and visualized using a UV transilluminator. DNA quantity was estimated by comparing the band intensities of each sample along with $\lambda$ DNA. The observed electrophoresed DNA samples were 
finally verified with Nanodrop ${ }^{\text {TM }}$ ND-1000 Spectrophotometer (Nanodrop Technologies Inc. USA). Part of the isolated DNA was diluted with TE buffer to make working concentration of $20 \mathrm{ng} / \mu \mathrm{l}$ and stored in deep freezer $\left(-20^{\circ} \mathrm{C}\right)$ until further use for PCR (Polymerase Chain Reaction) analysis.

\section{Source of SSRs and PCR analysis}

A total of 65 microsatellite markers identified for gladiolus and related genera/species available in public domain viz. cpSSRs [40], genomic SSRs [10, 20, 24, 47], EST derived SSRs from Iris spp. [50] and intergenic spacer sequences [41] were screened for amplification and detection of polymorphism among gladiolus genotypes. All primers were custom synthesized (Invitrogen, USA) and primers were dissolved by adding the appropriate quantity of TE buffer to finally yield $100 \mathrm{pmol} / \mu \mathrm{l}$ or $100 \mu \mathrm{mol}$ concentration and stored at $-20^{\circ} \mathrm{C}$. Primer working stocks prepared by adding $5 \mu \mathrm{l}$ forward and $5 \mu \mathrm{l}$ reverse primers in $90 \mu \mathrm{l}$ nuclease free water and stored at $4^{\circ} \mathrm{C}$. Initially, all synthesized primers were screened for amplification using gradient or Touch down PCR protocol in few randomly selected gladiolus genotypes to standardize the annealing temperature. PCR amplification was performed in a thermal cycler with flex gradient technology (peqSTAR ${ }^{\circledR}$, a VWR ${ }^{\mathrm{TM}}$ company, Germany) in $10 \mu$ reaction volume containing $2 \mu \mathrm{l}(20 \mathrm{ng} / \mu \mathrm{l})$ genomic DNA template, $1 \mu$ l of 10X Taq buffer, $1 \mu$ l dNTPs (10mM each), $2 \mu$ l of both forward and reverse primer, $0.3 \mu$ l 1U Taq DNA polymerase (Genei laboratories, Bengaluru) and 3.7 $\mu$ l of nuclease free water.

For most of the SSR primers, PCR thermal profile involved initial denaturation at $95^{\circ} \mathrm{C}$ for 4 min, followed by 35 cycles of denaturation at $94^{\circ} \mathrm{C}$ for $1 \mathrm{~min}$, annealing at $52^{\circ} \mathrm{C}-60^{\circ} \mathrm{C}$ (specific to each primer) for $45 \mathrm{sec}$, initial extension at $72^{\circ} \mathrm{C}$ for $2 \mathrm{~min}$ and a final extension at $72^{\circ} \mathrm{C}$ for $7 \mathrm{~min}$ before cooling down to $4^{\circ} \mathrm{C}$. Touch down PCR cycling programme was used for few SSRs with the following conditions: initial denaturation at $95^{\circ} \mathrm{C}$ for $5 \mathrm{~min}$, followed by 10 cycles of $95^{\circ} \mathrm{C}$ for $1 \mathrm{~min}$, annealing (with a touchdown of $59^{\circ} \mathrm{C}-54^{\circ} \mathrm{C},-0.5^{\circ} \mathrm{C}$ per cycle for GP 4 \& IM $39,50-45^{\circ} \mathrm{C},-0.5^{\circ} \mathrm{C}$ per cycle for IM 108 \& IM $123,55^{\circ} \mathrm{C}-50^{\circ} \mathrm{C},-0.5^{\circ} \mathrm{C}$ per cycle for IM 112) for $45 \mathrm{~s}$, and $72^{\circ} \mathrm{C}$ for $2 \mathrm{~min} ; 25$ cycles at $95^{\circ} \mathrm{C}$ for $1 \mathrm{~min}$, annealing $\left(54^{\circ} \mathrm{C}\right.$ for GP 4 \& IM 39, $45^{\circ} \mathrm{C}$ for IM 108 \& IM $123,50^{\circ} \mathrm{C}$ for IM 112) for $45 \mathrm{~S}$, and $72^{\circ} \mathrm{C}$ for 2 min; and a final extension at $72^{\circ} \mathrm{C}$ for $7 \mathrm{~min}$ before cooling down to $4^{\circ} \mathrm{C}$. Gel electrophoresis was performed to resolve PCR products using $3 \%$ agarose SFR ${ }^{\circledR}$ (Super Fine Agarose) in 1X TAE buffer. The resolved products were visualized under UV light and photographed by using gel documentation system (Syngene, USA). A 100bp DNA ladder (Fermentas International Inc.) was used as size standard to determine allele size. The details of primer names, sequences (5'-3'), optimized annealing temperature, allele size for amplified SSRs are given in Table S2.

\section{Polymorphism detection and genetic diversity analysis}

Clearly visible and consistently reproduced PCR fragments for each SSR primer were considered for manual scoring of bands. Alleles were scored as ' 1 ' (for presence), ' 0 ' (for absence) and ' 9 ' (missing data) for a particular band to generate binary data matrix. Total number of alleles for each amplified SSR marker was recorded across all the genotypes. The genotypic data thus obtained was subjected to calculate genetic diversity measures. Polymorphic information content (PIC) for each SSR loci was estimated by determining the frequency of alleles per locus using the formula i.e., PIC $=1$ $\sum(\mathrm{Pi})^{2}$ where, $\mathrm{P}_{\mathrm{i}}$ is the relative frequency of the ' $\mathrm{i}$ 'th' allele of a SSR loci [29]. The PIC value indicates the genetic variation and also discriminatory power of a marker. Primer resolving power (Rp) was calculated as per the formulae given by Prevost and Wilkinson (1999) i.e., $R_{p}=\sum l_{b}$, where ' $I_{b}$ ' is band informativeness $=[1-\{2(0.5-p)\}]$ and ' $p$ ' is the proportion of the genotypes containing the band. Marker index (MI) for each polymorphic SSR locus was calculated as described by Powell and coworkers [29]. Allelic differences at a single locus in a population needs to be quantified to measure genetic variation. Therefore, allelic diversity measures viz. observed number of alleles ( $\mathrm{Na})$, number of effective alleles $(\mathrm{Ne})$, Shannon's information index (I), observed heterozygosity $(\mathrm{Ho})$, expected heterozygosity $(\mathrm{He})$ and fixation index (F) were estimated using GenAlEx version 6.5 [26]. Further, Nei's gene diversity (h) and gene flow $\left(\mathrm{N}_{\mathrm{m}}=\right.$ 
$\left.\left.\left(1 / F_{s t}\right)-1\right) / 4\right)$ were estimated using the Popgene v.1.32 software. The Ewens-Watterson Test was performed to check neutrality of each microsatellite loci for whole population used in the study [21].

\section{Population structure analysis}

STRUCTURE v2.3.4 programme was used to study the underlying population structure among the 84 gladiolus genotypes based on the principle of Bayesian clustering [32]. The admixture model with correlated allelic frequencies was assumed considering the ancestry of individual genotype in the population. Twenty independent runs were assessed for each fixed $\Delta K$ ( 1 to 10) and each run consisted of 50,000 burn-in length and 1,00,000 MCMC (Markov Chain Monte Carlo) iterations. The optimum number of subpopulations was identified using STRUCTURE HARVESTER [9]. Individual genotype was assigned to a subpopulation if at least $70 \%$ of its estimated genome fraction value was derived from that group and genotypes with membership probabilities ( $Q$ value) less than 0.70 were assigned to a mixed group as admixture.

The SSR genotypic data with individuals assigned to two subpopulations was further used to compute AMOVA (analysis of molecular variance) using GenAlEx software. AMOVA genetically differentiates two subpopulations by partitioning total variation into within subpopulations, among individuals within subpopulation and among individuals within total population on the basis of allelic frequencies and the number of mutational differences between molecular haplotypes. Allelic patterns across two subpopulations depicting number of private alleles, common alleles, and abundant alleles were computed. Pair-wise $F_{\text {st }}$ values were estimated for genetic differentiation of subpopulations. Genetic diversity statistics to explain genetic variation between the subpopulations viz., observed number of alleles $(\mathrm{Na})$, number of effective alleles ( $\mathrm{Ne}$ ), Shannon's information index (I), observed heterozygosity (Ho), expected heterozygosity $(\mathrm{He})$, unbiased expected heterozygosity $(\mathrm{uHe})$ was calculated using the GenAlex 6.5.

\section{Cluster analysis}

The $0-1$ binary data was subjected to calculate pairwise genetic similarity matrix using Jaccard's coefficient. A radial UPGMA dendrogram was also constructed based on Neighbourhood Joining ( $\mathrm{NJ}$ ) Algorithm based on simple matching dissimilarity matrix with the help of DARwin 6.0.10 programme [28]. Robustness of each node of NJ tree was assessed with 5000-bootstrap replicates. Principal coordinate analysis (PCoA) was performed using GenAlEx v6.5 based on the pair-wise genetic distance matrix between the genotypes and the first two principal coordinates were plotted in twodimensional space.

\section{Results}

\section{PCR analysis and cross transferability}

A total of 65 SSRs belonging to gladiolus species and different genera of Iridaceae family were used to amplify DNA from 84 gladiolus genotypes. Genomic SSRs identified for Gladiolus palustris and EST-SSRs identified for Iris spp. revealed $66.66 \%$ and $48 \%$ cross amplification in all the selected gladiolus genotypes. However, few genomic SSRs from Herbertia zebrina and Sysirinchium micranthum could not show any amplification. 41 SSRs produced amplicons in all the gladiolus genotypes. Chloroplast derived SSRs, genomic SSRs and EST-SSRs revealed $100 \%, 60.71 \%$ and $48 \%$ amplification in all the gladiolus germplasm, respectively (Table 1). Source of SSR primers developed for different crop species and their amplification pattern among the gladiolus germplasm is given in Table S3. A total of 17 polymorphic SSRs were obtained which were further utilized in genetic analysis.

\section{Genetic diversity statistics}


Molecular profiling of 84 gladiolus genotypes using 17 polymorphic SSRs revealed a total 58 polymorphic loci ranging from 2 (G9) to 6 (GP4) in each locus with an average of 3.41 alleles per marker. Molecular information generated using 17 polymorphic SSRs is depicted in Table 2. PIC value for polymorphic loci ranged from 0.11 (G9) to 0.71 (G12) with an average value of 0.48 . Resolving power of primers varied between 1.95 (GP2) to 3.14 (G5) with an average of 2.48. Marker indices for each polymorphic SSR were ranged from 0.95 (G9) to 2.38 (GP4). Allele wise genetic diversity parameters for all the genotypes are represented in Table S6. Number of effective alleles were ranged from 1.07 (GP2) to 3.35 (G12) with an average of $2.04 \pm 0.2$. Average Shannon's information index was $0.76 \pm 0.09$ with maximum of 1.27 (G12) and minimum of 0.16 (GP2). Observed heterozygosity values were ranged from 0 (G9) to 0.75 (IM31) whereas expected heterozygosity or gene diversity values ranged from 0.06 (GP2) to 0.70 (G12) with an average value of $0.43 \pm 0.05$. Fixation index values ranged from -0.09 (IM31) to 1.00 (G9) with a mean value of $0.24 \pm 0.08$. Gene flow for each SSR loci was varied from 0.31 (GP2) to 144.84 (G9) with mean value of $54.61 \pm 22.02$. Nei's gene diversity values ranged from 0.06 (GP2) to 0.70 (G12). Based on Ewens-Watterson test, four non neutral microsatellite loci viz. G12, GP7, GP13 and IM31 were detected as their observed homozygosity values lied outside the lower and upper limit of $95 \%$ confidence interval (Table S4).

\section{Population structure and cluster analysis}

Population structure of gladiolus genotypes was analyzed using Bayesian model approach. All the genotypes were assigned to two distinct subgroups based on maximum likelihood and delta $\mathrm{K}$ value $(\Delta \mathrm{K}=2)$ by their inferred genome fraction value (Fig. S1). The structure depicted two sub-populations (S1 and S2) composed of gladiolus genotypes studied (Fig. 1). Out of 84 genotypes, 72 were assigned to two sub groups and 12 were retained in the mixed group as admixture. Sub-population 1 (green group) consisted of 35 genotypes representing 40.47\%, whereas sub-population 2 (red group) contained 37 genotypes representing $36.90 \%$ of the total number of the genotypes in the study. Analysis of molecular variance and $\mathrm{F}$ statistics differentiating subpopulations is presented in Table S7. Maximum variance (53.59\%) was revealed among individuals within subpopulations whereas $36.55 \%$ of variation observed among individuals within total population. However, $9.86 \%$ variation was noticed between two subpopulations. Fixation indices including $F_{S T}, F_{I S}$ and $F_{I T}$ values were $0.10,0.41$ and 0.46 . Subpopulation 1 had highest average genetic diversity parameters than subpopulation 2 viz. $\mathrm{Na}(3.12 \pm 0.26), \mathrm{Ne}(1.99 \pm 0.21), \mathrm{I}(0.73 \pm 0.10), \mathrm{Ho}(0.34 \pm 0.05)$ and $\mathrm{He}$ $(0.41 \pm 0.06)$ as shown in (Table S8). However, highest fixation index $(0.22 \pm 0.09)$ and percentage of polymorphic loci (100.00\%) was observed in subpopulation 2.

Radial UPGMA dendrogram created based on simple matching dissimilarity matrix differentiated 84 genotypes into two distinct major clusters with 42 genotypes each (Fig. 2). Composition of Cluster I and II was similar to the composition of subpopulation 1 and 2, respectively (Table S5). Coefficients of similarity for each pair of genotypes ranged from 0.44 to 0.97 with an average value of 0.72 . Highest degree of similarity was observed for the pair Dhanvantari and Fire Flame (0.97) followed by Neel Rekha and Yellow Star (0.96) and Pusa Archana and Pusa Bindiya (0.96). Lowest similarity coefficient values were observed for genotype pairs namely Punjab Dawn and Punjab Lemon Delight (0.44) and Arka Arti and Punjab Lemon Delight (0.44). Similarly, coefficients of dissimilarity ranged from 0.16 to 0.89 with an average value 0.48. Punjab Lemon Delight and Vicki Lin (0.89) had highest degree of dissimilarity.

Lowest degree of dissimilarity was observed between Pusa Archana and Pusa Bindiya (0.16). Principal coordinate analysis also depicted similar groupings as in population structure and UPGMA cluster. Principal coordinate 2 explained maximum variance of $21.28 \%$ followed by first principal coordinate with variance of $11.64 \%$ (Fig. S2).

\section{Discussion}

\section{Cross transferability and PCR amplification}


Molecular markers facilitate precise and quick varietal identification, germplasm characterization and conservation. Microsatellite markers have been most preferred in molecular studies because of their codominance, high discrimination power, multiallelic nature and cross transferability within genera/family. They are easy to use, cost effective and amenable to automation as compared to other markers. Development of novel SSRs for concerned species involves sequencing of targeted genomic regions and is a costly affair with absence of genomic information. Studies on deciphering genomic sequence in flower bulbs particularly in gladiolus is comparatively difficult due to high heterozygosity, polyploidy and huge genome size [17]. Under such circumstances, a common procedure to detect microsatellite loci for a target species is through cross species and cross genera transferability of SSRs [22]. Success of heterologous amplification relies on conserved nucleotide sequence among the flanking regions of phylogenetically similar species. In the present investigation, 17 highly polymorphic SSRs were detected from a set of 65 microsatellites reported within iridaceae family members. The polymorphic microsatellites included seven chloroplast SSRs of gladiolus, five genomic SSRs of Gladiolus palustris and five EST derived SSRs of Iris. Chloroplast SSRs have been widely used to study phylogenetic evolution of plants in recent years. It is established that chloroplast genome is characterized by conserved genic sequences, non-recombination and maternal inheritance in plants [34]. Out of 12 chloroplast SSRs identified by Singh and coworkers [40], seven were polymorphic among gladiolus genotypes. Chloroplast SSRs revealed higher level of diversity in rice and barley species in contrast to chloroplast derived RFLPs $[33,35]$. The microsatellites reported for Gladiolus palustris (tetraploid) showed positive cross species transferability $(66.66 \%)$ in gladiolus cultivars. This indicated presence of conserved genomic regions between Gladiolus palustris and modern gladiolus cultivars. Cross species amplification of these microsatellites has been also studied in individuals of Gladiolus imbricatus and Gladiolus tenuis [20]. In support of our findings, close genetic relationship between modern gladiolus cultivars and Gladiolus palustris was revealed using chloroplast DNA regions [42]. In addition, Iris EST-SSRs also portrayed successful cross genera amplification (48\%) in gladiolus. Our findings are consistent with prediction that suggested that cross-transferability of SSRs can vary from 50 to $100 \%$ within a genus, while transferability across genera is generally less than $50 \%$ [27]. SSR markers derived from ESTs or transcriptome have high rate of cross transferability as they are located very close to or within functional genes. Therefore, they are highly conserved and often show significant polymorphism among plant species [15]. Possibility of cross transferability is high when the repeat sequences and flanking region consisting selected primer region is conserved across taxa. In a similar line of study, Debener (2012) analyzed genetic diversity of Euphorbia pulcherrima accessions using EST SSRs developed for Euphorbia esula through cross species amplification [7]. In ornamentals, congeneric transferability of microsatellite markers has been investigated in Iris spp. [45], Aspidistra spp. [12] and cacti [2].

\section{Marker efficiency and allelic diversity measures}

Molecular profiling of 84 gladiolus genotypes using 17 polymorphic SSRs revealed that all were highly informative. Representative gel electrophoresis profiles for markers G5 and GP13 are presented in Fig. 3. Abundant polymorphism and more genomic coverage of molecular markers increases accuracy in genetic diversity studies. Amount of genotyping required for phylogenetic analysis of crop plants can be reduced with highly informative markers. According to Botstein et al (1980), a DNA marker with PIC value more than 0.5 is said to be highly informative [3]. PIC and $\mathrm{Rp}$ ( $>0.50$ and $>2.0$, respectively) values for most of the loci suggested that SSR markers were efficient enough to distinguish gladiolus germplasm in the study. Higher PIC value of SSR markers may be attributed to their codominant and multi allelic nature. Marker indices define total utility of marker system in estimating genetic variation within germplasm pool. GP4 had highest marker index value of 2.38. Estimates of PIC, RP and MI signify overall ability of such markers in detecting polymorphisms in the plant population and between any two genotypes or cultivars taken at random from that population, the overall utility of a marker for detecting genetic variation and infer genetic relationships between accessions [30]. In the current study, SSR markers showed comparatively higher polymorphism against those DNA markers used in earlier reports [36, 23, 4, 43]. 
Allele wise mean genetic diversity parameters ( $\mathrm{Na}, \mathrm{Ne}, \mathrm{I}, \mathrm{Ho}, \mathrm{He}, \mathrm{F}, \mathrm{h}, \mathrm{Havg} \& \mathrm{Nm}$ ) indicated effectiveness of these SSRs to characterize the gladiolus germplasm used in the present study. Average Nei's genetic diversity (equivalent to average expected heterozygosity) indicated higher frequency of heterozygotes at single locus when chosen randomly. Average expected heterozygosity was comparatively high than observed heterozygosity for tested SSRs. Inbreeding coefficient values for most of the SSRs were low suggesting less fixation of alleles. Average estimated gene flow revealed high allelic diversity among gladiolus genotypes. Similarly, allelic diversity has been estimated using ESTSSRs in Iris spp. [50, 45,49] and genomic SSRs in crocus [24], herbertia [10] and gladiolus [20]. Non neutral markers detected based on Ewens Watterson test indicated their possible linkage to phenotypic traits or genes under selection. Kirk and Freeland (2011) suggested that non neutral markers may show unusual genetic divergence for traits under selection [16].

\section{Population structure and cluster analysis}

STRUCTURE analysis based on Bayesian approach grouped the overall gladiolus germplasm into two subpopulations however, no clear distinction among the Indian and exotic germplasm was established. Exotic genotypes could not be demarcated from Indian bred genotypes because introduced exotic gladioli have been used as parents in crossing programme and therefore fall within pedigree of Indian genotypes (Table S1). It has been known that no gladiolus species is native to India and it was introduced to India in later part of 19th century. Cultivated gladioli (Gladiolus $x$ grandiflorus) are complex hybrids and have been evolved from interspecific hybridization among wild species viz. Gladiolus cardinalis, Gladiolus daleni, Gladiolus oppositiflorus, Gladiolus papilio, Gladiolus carneus, Gladiolus cruentus, Gladiolus tristis and Gladiolus saundersii [13]. In a similar line of study, Choudhary et al (2018) revealed presence of mixed population among gladiolus germplasm while analyzing STRUCTURE of 53 gladiolus genotypes using ISSR markers [4]. AMOVA results showed minor variation between two subpopulations whereas individuals within total population depicted maximum variance. Wright's $\mathrm{F}$ statistics differentiated whole germplasm into two subdivided population based on level of allele frequencies shared among individuals. According to Vicente et al (2004), if $F_{S T}$ value is within the range of $0.05-0.15$, then subpopulations are assumed to be moderately differentiated at genetic level [5, 6]. Moderate $\left(\mathrm{F}_{\mathrm{ST}}=0.10\right)$ genetic differentiation of allelic frequencies was observed among two subpopulations. Average heterozygotes in each subpopulation $\left(F_{I T}=0.41\right)$ and among subpopulations $\left(F_{I T}=0.46\right)$ indicated existence of large non-random mating among individuals within subpopulations. This may be attributed to complex ploidy level, high heterozygosity and cross pollination nature of gladiolus. Various factors including pollen movement, germplasm exchange, natural selection, reproduction system and geographical distribution decide the level of variability existing among the populations. Subpopulation 1 was genetically more diverse than subpopulation 2 accounting highest average genetic diversity estimates ( $\mathrm{Na}, \mathrm{Ne}, \mathrm{l}, \mathrm{Ho}$, and $\mathrm{He}$ ).

\section{Genetic relationships}

In our study, the grouping pattern arising from STRUCTURE were consistent with those obtained from UPGMA dendrogram and PCoA in terms of genotype number and composition of clusters excluding few admixtures. A detailed insight into genetic relationship among gladiolus varieties was inferred from polymorphic SSR data based on Jaccard's similarity matrix and UPGMA clustering. Two major clusters containing 42 genotypes each were identified at an average pairwise similarity of 0.49 based on Jaccard's similarity matrix. Highest degree of similarity for cultivar pairs viz. Dhanvantari - Fire Flame (Jaccard's coefficient $=0.97)$ followed by Yellow Star - Neel Rekha $($ Jaccard's coefficient $=$ 0.96) was recorded and it was evident from their close presence in Cluster II, while lowest degree of similarity between cultivar pairs viz. Punjab Dawn - Punjab Lemon Delight and Arka Arti - Punjab Lemon Delight was observed and thus their presence in different clusters could be noticed. Based on simple matching dissimilarity matrix, Punjab Lemon Delight - Vicki Lin (coefficient of dissimilarity $=0.89$ ) had highest degree of dissimilarity. Presence of Punjab Lemon 
Delight - Vicki Lin in cluster I and II respectively, could be justified to their clustering pattern. Punjab Lemon Delight and Vicki Lin were found genetically distinct among gladiolus genotypes used in the study.

Cultivar pairs which shared common parent/s (either male/female or both) in their derivation were found closely spaced in cluster I. Indian bred cultivars namely Arka Amar (Watermelon Pink × Arka Aarti), Arka Darshan (Watermelon Pink $\times$ Shirley), Arka Sapna (Green Woodpecker $\times$ Friendship), Pusa Chandni (Green Woodpecker $\times$ White Butterfly), Punjab Glad 1 (Happy End $\times$ True Yellow) and Punjab Glance (Happy End $\times$ Yellow Stone) were grouped together owing to common female parent during hybridization. While Punjab Pink Elegance (Suchitra $\times$ White Prosperity) and Punjab Lemon Delight (Jacksonville Gold $\times$ White Prosperity) were noticed in the same cluster showing similarity in their male parentage. Thus, presence of Suchitra, Jacksonville Gold and Yellow Stone in the same group could be highly obvious. Occurrence of Pusa Sarang (OP seedling obtained from 'White Oak'), Pusa Shagun (White Oak $\times$ Oscar), Pusa Mohini (Ave $\times$ Christian Jane) and Pusa Kiran (OP seedling obtained from 'Ave') in cluster I was evident showing their affinity towards parentage. However, rest of the genotypes could not share any common parentage but clustered together. This might be attributed to highly heterozygous nature of crop.

Correspondingly, cluster II was also formed by the genotypes sharing common lineage. Presence of Punjab Dawn (Suchitra $\times$ Melody), Arka Arti (Shirley $\times$ Melody), Amethyst (Lavender Puff $\times$ Tropic Sea), Neelima (Snow Princess $\times$ Tropic Sea), Arka Naveen (74-39-1 $\times$ Tropic Sea), Pusa Sringarika (Mayur $\times$ Heady Wine) and Pusa Urmi (Berlew $\times$ Heady Wine) in cluster II might be attributed to owing to their common male parentage during crossing. Similarly, Punjab Morning (Sancerre $\times$ White Prosperity) and Anjali (Sancerre $\times$ Rose Spire) were placed close together with female parent 'Sancerre'. Malaviya Shatabdi, an induced mutant of Punjab Dawn was also present in this cluster. Kalima and Pusa Suhagin were open pollinated seedlings of Sylvia and found related to each other in this cluster. Even though Pusa Srijana and Pusa Urmi had common parentage i.e., Berlew $\times$ Heady Wine, however, their presence in cluster I and II, respectively might be due to chance similarity in their parentage at genotypic level. Few genotypes could not share any common parentage were also grouped together in both the clusters because of greater degree of similarity in genetic constitution of ancestors. It was also suggested that chloroplast SSRs or EST derived SSRs may not differentiate the related species and cultivars due to conserved genome or positions within genic regions in the genome of ancestors. However, pedigree information was not available for some of the genotypes as it is essential for comparative analysis with SSR profiles. In general, our results were more consistent with clustering pattern obtained based on AFLP [36], RAPD [31] and ISSR [4] data. In a similar study, Singh et al analyzed phylogenetic relationship among gladiolus cultivars using sequenced chloroplast DNA regions [42].

\section{Conclusion}

To conclude our study, we are first to report cross transferability of SSRs developed for Gladiolus palustris and Iris spp. to analyze genetic diversity, population structure and genetic relationships among cultivated/modern gladiolus genotypes. Microsatellite markers used in the current study have great discriminatory power and highly informative to study genetic diversity and molecular characterization of gladiolus germplasm. However, genetic variability obtained in STRUCTURE of gladiolus germplasm was narrow indicating use of limited gene pool in breeding new varieties.

Identified SSRs will be helpful for identification, documentation and conservation of gladiolus varieties and also can be very useful in marker assisted breeding programme. These markers also help in protection against unauthorized commercialization of varieties and protection of plant breeder rights.

\section{Declarations}

Funding: Not applicable 
Conflict of interest: The authors declare that they have no conflict of interest.

Availability of data and material: Not applicable

Code availability: Not applicable

\section{Author's contributions}

Conceptualization of research (KPS, NJ); Designing of the experiments (NJ, KPS); Contribution of experimental materials (KS, KPS, NJ, PKJ); Execution of field/lab experiments and data collection (VMH); Analysis of data and interpretation (VMH, NJ, NS); Preparation of the manuscript (VMH, NJ, SP). All the authors read the manuscript and approved the final draft of it.

Ethics approval: This research article does not involve any studies related to animals or humans

Consent to participate: Not applicable

Consent for publication: Not applicable

\section{Acknowledgements}

The first author expresses sincere gratitude to ICAR-Indian Agricultural Research Institute, New Delhi for providing Senior Research Fellowship for his Doctoral research work. First author gratefully acknowledges Wheat Molecular Biology and Biotechnology Lab, Division of Genetics, ICAR-IARI for providing laboratory facilities.

\section{References}

1. Barnard TT (1972) On hybrid and hybridization. In: Lewis GJ, Obermeyer AA, Barnard TT (eds) Gladiolus, a revision of the South African species. J South African Bot 10: 304 - 310

2. Bombonato JR, Bonatelli IAS, Silva GAR, Moraes EM, Zappi DC, Taylor NP, Franco FF (2019) Cross-genera SSR transferability in cacti revealed by a case study using Cereus (Cereae, Cactaceae). Genet Mol Biol 42(1):87-94

3. Botstein D, White RL, Skolnick M, Davis RW (1980) Construction of a genetic linkage map in man using restriction fragment length polymorphisms. American J Human Gen 32(3):314-331

4. Chaudhary V, Kumar M, Sharma S, Kumar N, Kumar V, Yadav HK, Sirohi U (2018) Assessment of genetic diversity and population structure in gladiolus (Gladiolus hybridus Hort.) by ISSR markers. Physiol Mol Biol Plants 24(3):493-501

5. De Vicente MC, Guzmán FA, Engels J, Rao VA (2006) Genetic characterization and its use in decision - making for the conservation of crop germplasm. In: Ruane J, Sonnino A (eds) The Role of Biotechnology in Exploring and Protecting Agricultural Genetic Resources. FAO of the United Nations, Rome, pp 129-138

6. De Vicente MC, Lopez C, Fulton T (2004) Genetic diversity analysis with molecular marker data: learning module. International Plant Genetic Resources Institute (PGRI), Rome

7. Debener T (2012) Molecular markers for ornamental plant genetics, genomics and breeding. Acta Hort 953:193200

8. Doyle JJ, Doyle JL (1990) Isolation of plant DNA from fresh tissue. Focus 12(13):39-40

9. Evanno G, Regnaut S, Goudet J (2005) Detecting the number of clusters of individuals using the software STRUCTURE: a simulation study. Mol Ecol 14(8):2611-2620 
10. Forgiarini C, Curto M, Stiehl-Alves EM, Brauchler C, Kollmann J, Meimberg H, Souza-Chies TTD (2017) Fifteen microsatellite markers for Herbertia zebrina (Iridaceae): An endangered species from South American grasslands. Appl Plant Sci 5(5):e1700035

11. Heckenberger M, Muminovic J, Rouppe van der Voort J, Peleman J, Bohn M, Melchinger AE (2006) Identification of essentially derived varieties from biparental crosses of homogenous lines: III. AFLP data from maize inbreds and comparison with SSR data. Mol Breed 17:111-125

12. Huang D, Zhang Y, Jin M, Li H, Song Z, Wang Y, Chen J (2014) Characterization and high cross-species transferability of microsatellite markers from the floral transcriptome of Aspidistra saxicola (Asparagaceae). Mol Ecol Res 14(3):569-577

13. Huxley A, Griffiths M, Levy M (1992) Gladiolus. In: Griffiths M, Huxley AJ (eds) The New Royal Horticultural Society Dictionary of Gardening, vol 2. Stockton Press, New York

14. Imanishi H (1989) Gladiolus. In: Matsuo T (ed) Collected data of plant genetic resources. Kodansha Sci, pp. 10771080

15. Kalia RK, Rai MK, Kalia S, Singh R, Dhawan AK (2011) Microsatellite markers: an overview of the recent progress in plants. Euphytica 177(3):309-334

16. Kirk H, Freeland JR (2011) Applications and implications of neutral versus non-neutral markers in molecular ecology. International J Mol Sci 12(6):3966-3988

17. Krens FA, Kamo K (2013) Genomic tools and prospects for new breeding techniques in flower bulb crops. Acta Hortic 974:137-147

18. Kutlunina N, Permyakova M, Belyaev A (2017) Genetic diversity and reproductive traits in triploid and tetraploid populations of Gladiolus tenuis (Iridaceae). Plant Syst Evol 303(1):1-10

19. Liu C, Zhang X, Xu Q, Xian F (2009) AFLP analysis on dual colour flower gladiolus mutants induced by radiation. Acta Bot Sin 29(1):69-74

20. Malkocs T, Almerekova S, Bereczki J, Cservenka J, Meglecz E, Sramko G (2019) Isolation and characterization of 15 SSR loci for the endangered European tetraploid species Gladiolus palustris (Iridaceae). Appl Plant Sci 7(5):e01245

21. Manly BF (1985) Tests of the theory of natural selection: an overview. J Royal Soc New Zealand 15(4):411-432

22. Moreno AC, Marchelli P, Vendramin GG, Gallo LA (2011) Cross transferability of SSRs to five species of Araucariaceae: a useful tool for population genetc studis in" Araucaria araucana". Forest sys 20(2):303-314

23. Nasir IA, Jamal A, Rahman Z, Husnain T (2012) Molecular analysis of gladiolus lines with improved resistance against fusarium wilt. Pakistan J Bot 44(1):73-79

24. Nemati Z, Zeinalabedini M, Mardi M, Pirseyediand SM, Marashi SH, Khayam Nekoui SM (2012) Isolation and characterization of a first set of polymorphic microsatellite markers in saffron, Crocus sativus (Iridaceae).

American J Bot 99(9):340-343

25. Ohri D, Khoshoo TN (1983) Cytogenetics of garden Gladiolus IV. Origin and evolution of ornamental taxa. Proc Nat Acad Sci USA 49:279-294

26. Peakall R, Smouse PE (2012) GenAlEx 6.5: Genetic analysis in excel. Population genetic software for teaching and research - an update. Bioinformatics 28:2537-2539

27. Peakall R, Gilmore S, Keys W, Morgante M, Rafalski A (1998) Cross-species amplification of soybean (Glycine max) simple sequence repeats (SSRs) within the genus and other legume genera: implications for the transferability of SSRs in plants. Mol Biol Evol 15(10):1275-1287

28. Perrier X, Jacquemoud-Collet JP (2006) DARwin software, http://darwin.cirad.fr/darwin

Page $11 / 17$ 
29. Powell W, Machray GC, Provan J (1996a) Polymorphism revealed by simple sequence repeats. Trends in Plant Sci 1(7):215-222

30. Powell W, Morgante M, Andre C, Hanafey M, Vogel J, Tingey S, Rafalski A (1996b) The comparison of RFLP, RAPD, AFLP and SSR (microsatellite) markers for germplasm analysis. Mol Breed 2(3):225-238

31. Pragya Bhat KV, Misra RL, Ranjan JK (2010) Analysis of diversity and relationships among gladiolus cultivars using morphological and RAPD markers. Indian J Agric Sci 80(90):766-772

32. Pritchard JK, Stephens M, Donnelly P (2000) Inference of population structure using multilocus genotype data. Genet 155(2):945-959

33. Provan J, Corbett G, Powell W, McNicol JW (1997) Chloroplast DNA variability in wild and cultivated rice (Oryza spp.) revealed by polymorphic chloroplast simple sequence repeats. Genome 40(1):104-110

34. Provan J, Powell W, Hollingsworth PM (2001) Chloroplast microsatellites: new tools for studies in plant ecology and evolution. Trends in ecol evol 16(3):142-147

35. Provan J, Russell JR, Booth A, Powell W (1999) Polymorphic chloroplast simple sequence repeat primers for systematic and population studies in the genus Hordeum. Mol Ecol 8(3):505-511

36. Ranjan P, Bhat KV, Mishra RL, Singh SK, Ranjan JK (2010) Genetic relationship of gladiolus cultivars inferred from fluorescence based AFLP markers. Sci Hortic 123:562-567

37. Raycheva T, Stoyanov K, Denev I (2011) Genetic diversity and molecular taxonomy study of three genera from Iridaceae family in the Bulgarian flora based on ISSR markers. Biotech Biotechnol Equip 25(3):2484-2488

38. Rossetto M (2001) Sourcing of SSR markers from related plant species. Plant genotyping: the DNA fingerprinting of plants 1:211-224

39. Rymer PD, Manning JC, Goldblatt P, Powell MP, Savolainen V (2010) Evidence of recent and continuous speciation in a biodiversity hotspot: a population genetic approach in southern African gladioli (Gladiolus; Iridaceae). Mol Ecol 19(21):4765-4782

40. Singh N, Pal AK, Roy RK, Tamta S, Rana TS (2017a) Development of cpSSR markers for analysis of genetic diversity in gladiolus cultivars. Plant Genet 10:31-36

41. Singh N, Pal AK, Meena B, Roy RK, Tamta S, Rana TS (2017b) Development of ISSR and RAPD - derived SCAR markers for identification of gladiolus germplasm. J Hortic Sci Biotechnol 92(6):577-582

42. Singh N, Meena B, Pal AK, Roy RK, Tewari SK, Tamta S, Rana TS (2017c) Nucleotide diversity and phylogenetic relationships among gladiolus cultivars and related taxa of family Iridaceae. J Genet 96(1):135-145

43. Singh N, Pal AK, Roy RK, Tewari SK, Tamta S, Rana TS (2018) Characterization of gladiolus germplasm using morphological, physiological and molecular markers. Biochem Genet 56(1-2):128-148

44. Squirrell J, Hollingsworth PM, Woodhead M, Russell J, Lowe AJ, Gibby M, Powell W (2003) How much effort is required to isolate nuclear microsatellites from plants? Mol Ecol 12(6):1339-1348

45. Sun MZ, Li MR, Shi FX, Li L, Liu Y, Li LF, Xiao HX (2012) Genomic and EST derived microsatellite markers for Iris laevigata (Iridaceae) and other congeneric species. American J Bot 99(7):286-288

46. Szczepaniak M, Kaminski R, Kuta E, Słomka A, Heise W, Cieslak E (2016) Natural hybridization between Gladiolus palustris and Gladiolus imbricatus inferred from morphological, molecular and reproductive evidence. Preslia 88(1):137-161

47. Tacuatiá LO, Cidade FW, Souza AP, Souza-Chies TT (2012) Development and characterization of nine microsatellite loci for Sisyrinchium micranthum (Iridaceae). American J Bot 99(10):402-404

48. Takahashi Y, Yokoi S, Takahata Y (2016) Genetic divergence of turnip (Brassica rapa L. em. Metzg. subsp. rapa) inferred from simple sequence repeats in chloroplast and nuclear genomes and morphology. Genetic Res Crop 
Evol 63(5):869-879

49. Tang DQ, Sun Y, Li X, Yan Z, Shi YM (2018) De novo sequencing of the freesia hybrida petal transcriptome to discover putative anthocyanin biosynthetic genes and develop EST-SSR markers. Acta Physiol Plant 40(9):168

50. Tang S, Okashah RA, Cordonnier-Pratt MM, Pratt LH, Johnson VE, Taylor CA, Knapp SJ (2009) EST and EST - SSR marker resources for Iris. BMC Plant Biol 9(1):72

\section{Tables}

Table 1

SSR markers used in the study and their amplification pattern

\begin{tabular}{|llllll|}
\hline $\begin{array}{l}\text { Sl. } \\
\text { No. }\end{array}$ & $\begin{array}{l}\text { Type of marker } \\
\text { (species/genera derived from) }\end{array}$ & $\begin{array}{l}\text { No. of } \\
\text { screened } \\
\text { primers }\end{array}$ & $\begin{array}{l}\text { No. of } \\
\text { amplified } \\
\text { primers }\end{array}$ & $\begin{array}{l}\text { Amplification } \\
\%\end{array}$ & $\begin{array}{l}\text { \% of } \\
\text { polymorphic } \\
\text { markers }\end{array}$ \\
\hline 1 & Chloroplast derived SSRs (Gladiolus) & 12 & 12 & 100 & 58.33 \\
\hline 2 & $\begin{array}{l}\text { Genomic SSRs } \\
\text { (Gladiolus palustris, Crocus sativus, Herbertia } \\
\text { zebrina, Sysirinchium micranthum \& } \\
\text { Chloroplast DNA regions) }\end{array}$ & 28 & 17 & 60.71 & 29.41 \\
\hline 3 & EST derived SSRs (Iris spp.) & 25 & 12 & 48.00 & 41.66 \\
\hline
\end{tabular}


Table 2

Data on allelic diversity generated from 17 polymorphic SSRs in gladiolus

\begin{tabular}{|c|c|c|c|c|c|c|c|c|c|}
\hline $\begin{array}{l}\text { Sl. } \\
\text { No }\end{array}$ & $\begin{array}{l}\text { Marker } \\
\text { name }\end{array}$ & Primer (5'-3') & Source & $\begin{array}{l}\mathrm{Tm} \\
\left({ }^{\circ} \mathrm{C}\right)\end{array}$ & PF & $\begin{array}{l}\text { Allele } \\
\text { size } \\
\text { range } \\
\text { (bp) }\end{array}$ & PIC & $\mathbf{R}_{\mathbf{P}}$ & MI \\
\hline 1 & G5 & $\begin{array}{l}\text { F: GCTCACAACAATAATCCTTCCC } \\
\text { R: CAATGAACTCAGCAATACCAGC }\end{array}$ & $\begin{array}{l}\text { Singh et } \\
\text { al., } 2017\end{array}$ & 60 & 4 & $\begin{array}{l}270- \\
300\end{array}$ & 0.64 & 3.14 & 1.91 \\
\hline 2 & G7 & $\begin{array}{l}\text { F: GTGTCTTCGGTGCTTTTCTCTT } \\
\text { R: CAGCGATAACCTAGAACGAACA }\end{array}$ & $\begin{array}{l}\text { Singh et } \\
\text { al., } 2017\end{array}$ & 60 & 4 & $\begin{array}{l}260- \\
320\end{array}$ & 0.29 & 2.00 & 1.91 \\
\hline 3 & G8 & $\begin{array}{l}\text { F: TCTATGTCAGTGCTCTACCGGA } \\
\text { R: GAAGCAAACGAGTCTGTGGAC }\end{array}$ & $\begin{array}{l}\text { Singh et } \\
\text { al., } 2017\end{array}$ & 60 & 3 & $\begin{array}{l}280- \\
300\end{array}$ & 0.62 & 2.36 & 1.43 \\
\hline 4 & G9 & $\begin{array}{l}\text { F: TATAGAGGAATGCGTGTCCGAT } \\
\text { R: TACTGCATGACGAGGAAATCAC }\end{array}$ & $\begin{array}{l}\text { Singh et } \\
\text { al., } 2017\end{array}$ & 60 & 2 & $\begin{array}{l}400- \\
420\end{array}$ & 0.11 & 2.00 & 0.95 \\
\hline 5 & G10 & $\begin{array}{l}\text { F: TGCCACTCCAGCATAACTTCTA } \\
\text { R: ACTCCTTTTCCTCCCATTCTTC }\end{array}$ & $\begin{array}{l}\text { Singh et } \\
\text { al., } 2017\end{array}$ & 60 & 4 & $\begin{array}{l}310- \\
330\end{array}$ & 0.45 & 2.36 & 1.91 \\
\hline 6 & G11 & $\begin{array}{l}\text { F: AAAGTCCCTCCTCTCCTCTGAT } \\
\text { R: GAGCTTGTTACTGAACGGAACC }\end{array}$ & $\begin{array}{l}\text { Singh et } \\
\text { al., } 2017\end{array}$ & 60 & 3 & $\begin{array}{l}480- \\
510\end{array}$ & 0.64 & 2.60 & 1.43 \\
\hline 7 & G12 & $\begin{array}{l}\text { F: GGCATCCTTCCTCTCCGT } \\
\text { R: CGGCCTTGGGTGTAGAAGTAG }\end{array}$ & $\begin{array}{l}\text { Singh et } \\
\text { al., } 2017\end{array}$ & 60 & 4 & $\begin{array}{l}200- \\
240\end{array}$ & 0.71 & 2.79 & 1.91 \\
\hline 8 & GP 2 & $\begin{array}{l}\text { F: TTGTTACTGGTGCGGACTCC } \\
\text { R: CAGGTCCGATTGCTTGAGGA }\end{array}$ & $\begin{array}{l}\text { Malkocs } \\
\text { et al., } \\
2019\end{array}$ & 58 & 3 & $\begin{array}{l}210- \\
270\end{array}$ & 0.12 & 1.95 & 1.43 \\
\hline 9 & GP 4 & $\begin{array}{l}\text { F: ATGCCTTTGTCCTCTCACCT } \\
\text { R: TTTGTCCCTAATTGGAACACGTC }\end{array}$ & $\begin{array}{l}\text { Malkocs } \\
\text { et al., } \\
2019\end{array}$ & 54 & 6 & $\begin{array}{l}180- \\
310\end{array}$ & 0.52 & 2.17 & 2.38 \\
\hline 10 & GP 7 & $\begin{array}{l}\text { F: CCAAGTAAGTGATGGCGGC } \\
\text { R: GGGTCTAGAGAAGGCTTGGG }\end{array}$ & $\begin{array}{l}\text { Malkocs } \\
\text { et al., } \\
2019\end{array}$ & 56 & 3 & $\begin{array}{l}190- \\
210\end{array}$ & 0.66 & 2.62 & 1.44 \\
\hline 11 & GP 13 & $\begin{array}{l}\text { F: AAACCCTCACTTCGGAGATCA } \\
\text { R:TAAAGTCAGTCAGCTGTAACACTG }\end{array}$ & $\begin{array}{l}\text { Malkocs } \\
\text { et al., } \\
2019\end{array}$ & 54 & 3 & $\begin{array}{l}280- \\
300\end{array}$ & 0.66 & 2.67 & 1.44 \\
\hline 12 & GP 15 & $\begin{array}{l}\text { F: GGGTCATCGCCTGTCATGAA } \\
\text { R: TCGTATCGGCTTGTTGGCTG }\end{array}$ & $\begin{array}{l}\text { Malkocs } \\
\text { et al., } \\
2019\end{array}$ & 54 & 4 & $\begin{array}{l}190- \\
210\end{array}$ & 0.68 & 3.05 & 1.91 \\
\hline 13 & IM 31 & $\begin{array}{l}\text { F: AAGCAAAAGGTTTTCCATTCC } \\
\text { R: GTTTCTTGTCGAGGAACATGC }\end{array}$ & $\begin{array}{l}\text { Tang et } \\
\text { al., } 2009\end{array}$ & 52 & 4 & $\begin{array}{l}300- \\
420\end{array}$ & 0.69 & 2.90 & 1.91 \\
\hline 14 & IM 86 & $\begin{array}{l}\text { F: GGGTTTGTATTGTTTGTTGGAGA } \\
\text { R: GGGTGATGTGGTCCTTGTAGA }\end{array}$ & $\begin{array}{l}\text { Tang et } \\
\text { al., } 2009\end{array}$ & 60 & 2 & $\begin{array}{l}200- \\
220\end{array}$ & 0.21 & 2.00 & 0.96 \\
\hline 15 & IM 108 & $\begin{array}{l}\text { F: TCTCCTCCTGTCCGTCTATCC } \\
\text { R: AGTCGTCCAAATCTCCGAACT }\end{array}$ & $\begin{array}{l}\text { Tang et } \\
\text { al., } 2009\end{array}$ & 45 & 2 & $\begin{array}{l}320- \\
390\end{array}$ & 0.45 & 2.43 & 0.96 \\
\hline 16 & IM 39 & $\begin{array}{l}\text { F: CCCTAGCAAACATCTCTTCCA } \\
\text { R: TGTTATCAGCAAGCAGTCCAG }\end{array}$ & $\begin{array}{l}\text { Tang et } \\
\text { al., } 2009\end{array}$ & 54 & 3 & $\begin{array}{l}380- \\
500\end{array}$ & 0.25 & 2.00 & 1.44 \\
\hline 17 & IM 224 & $\begin{array}{l}\text { F: AGAGAAGAGAGCATGGCGATA } \\
\text { R: GCGAGAAGTGGCATAAAGAGA }\end{array}$ & $\begin{array}{l}\text { Tang et } \\
\text { al., } 2009\end{array}$ & 46 & 4 & $\begin{array}{l}200- \\
280\end{array}$ & 0.41 & 2.07 & 1.91 \\
\hline
\end{tabular}




\begin{tabular}{|c|c|c|c|c|c|c|c|c|c|}
\hline $\begin{array}{l}\text { Sl. } \\
\text { No }\end{array}$ & $\begin{array}{l}\text { Marker } \\
\text { name }\end{array}$ & Primer (5'-3') & Source & $\begin{array}{l}\mathrm{Tm} \\
\left({ }^{\circ} \mathrm{C}\right)\end{array}$ & PF & $\begin{array}{l}\text { Allele } \\
\text { size } \\
\text { range } \\
\text { (bp) }\end{array}$ & PIC & $\mathrm{R}_{\mathrm{P}}$ & MI \\
\hline Tot & & & & & 58 & & 8.11 & 42.10 & 27.27 \\
\hline Ave & & & & & 3.41 & & 0.48 & 2.48 & 1.60 \\
\hline
\end{tabular}

\section{Figures}

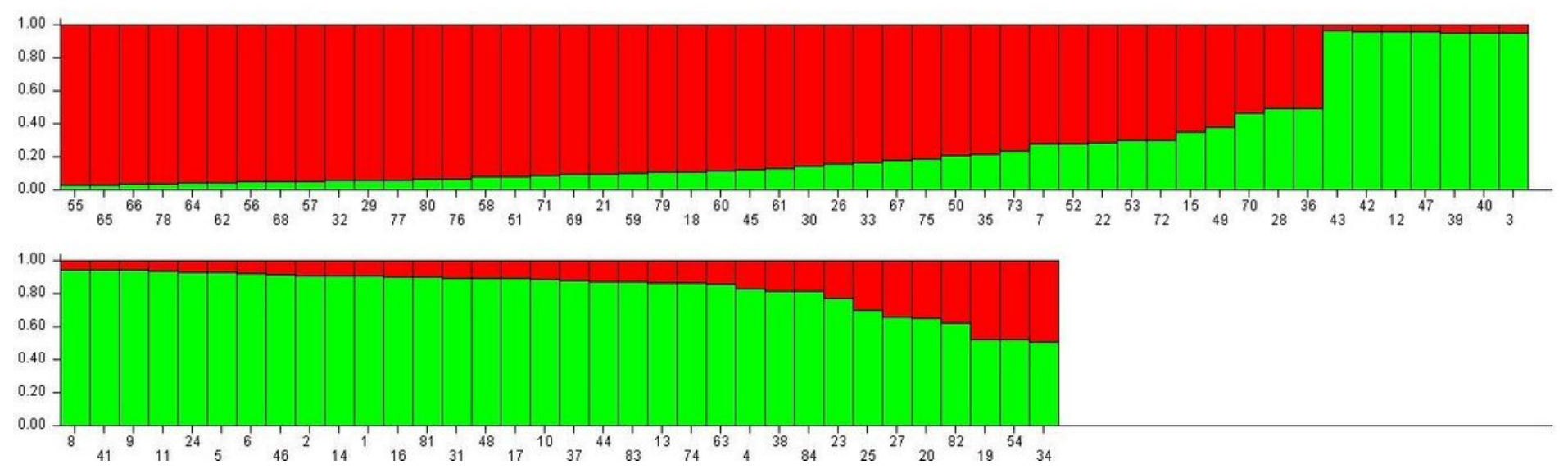

\section{Figure 1}

Estimated population structure of 84 gladiolus genotypes as revealed by 17 polymorphic SSR markers for $\Delta \mathrm{K}=2$, Green color indicates sub-population 1, Red color indicates sub-population 2. 


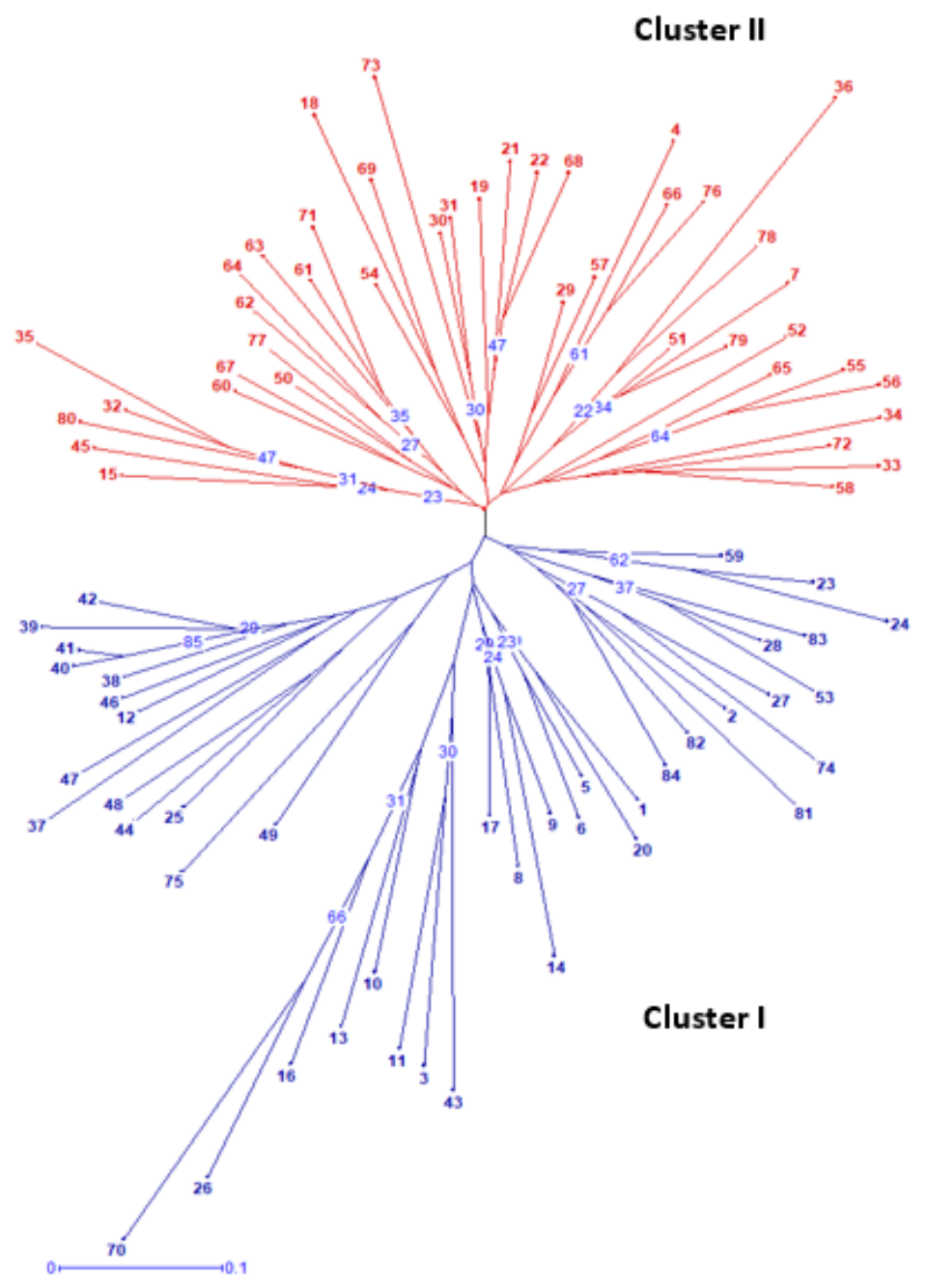

\section{Figure 2}

Radial UPGMA dendrogram of 84 gladiolus genotypes constructed based on simple matching dissimilarity coefficient matrix using 17 polymorphic SSRs. The numerical values representing the different genotypes are the genotype ID given in the Table S5. The numbers in blue color within tree nodes represents respective bootstrap values 


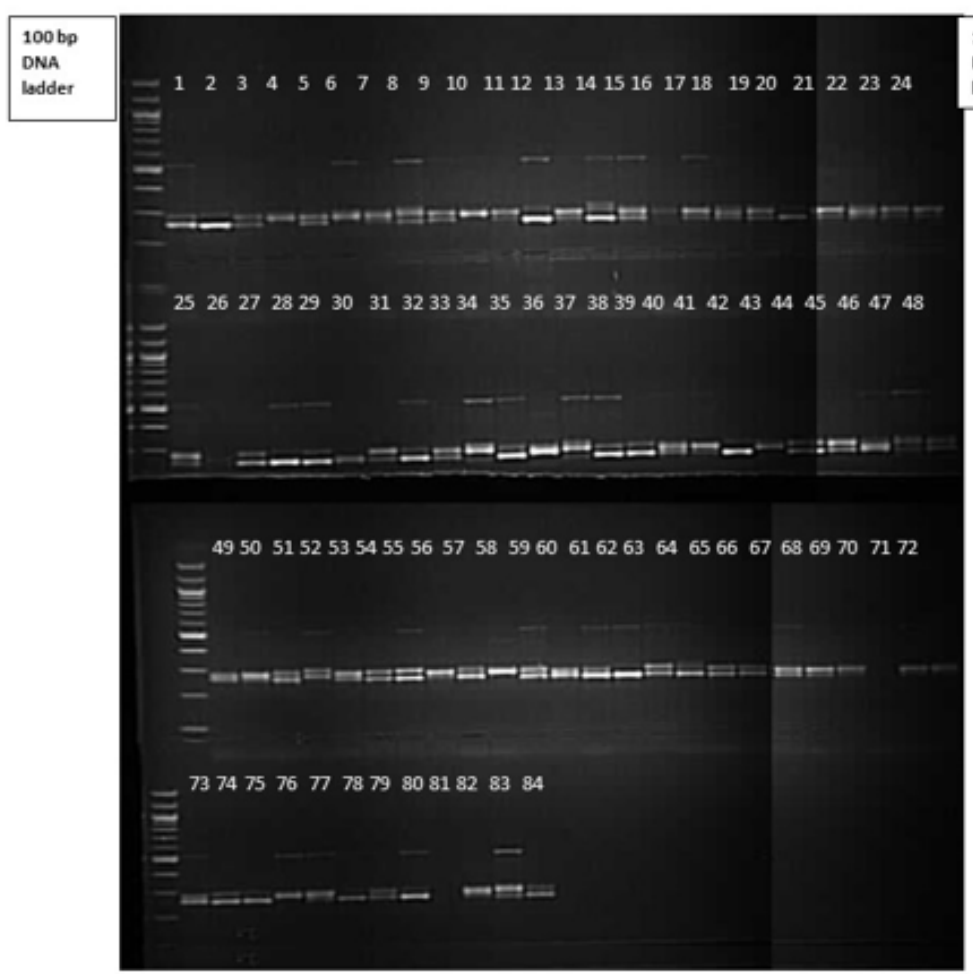

G5

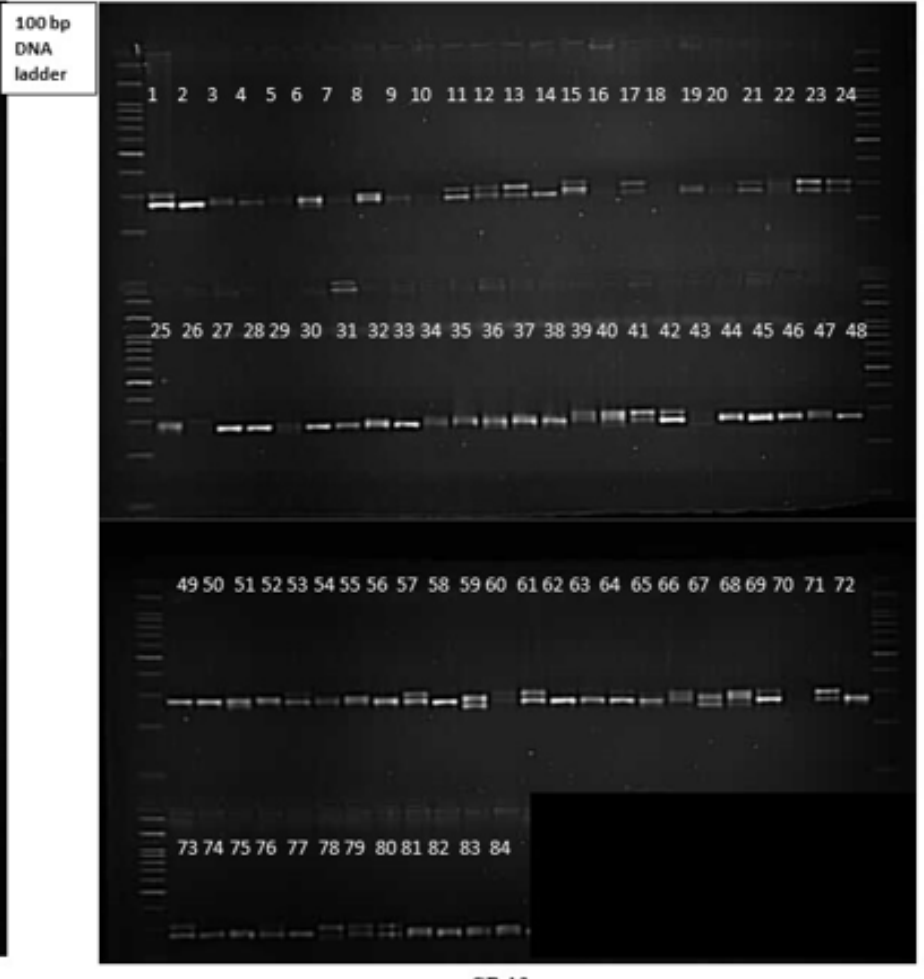

GP 13

\section{Figure 3}

Gel electrophoresis profile of 84 gladiolus genotypes revealed by G5 and GP13

\section{Supplementary Files}

This is a list of supplementary files associated with this preprint. Click to download.

- Supplementarytables.xls 